\title{
Serendipity: Reflections on Being Mentored by Dr. Peter Doherty
}

\author{
David J. Topham
}

\begin{abstract}
This is a semiautobiographical and scientific account of my time in the Doherty Laboratory from 1994 to 1999. It includes personal vignettes as well as discussion of how our work has impacted the fields of influenza, respiratory infections and immunity. I also point out the long-term impacts on my career.
\end{abstract}

Keywords: influenza, T cell, immunity, limiting dilution, parainfluenza

$\mathbf{W}$ HILE WORKING on my PhD at Vanderbilt University in Nashville, TN, I had the good luck of crossing paths with Peter Doherty for the first time at the 1993 Neuroimmunology Gordon Conference at Colby Sawyer College in New London, NH (Fig. 1). My PhD project investigated the cellular immune mechanism by which encephalomyocarditis virus causes paralysis. Dr. Subramaniam Sriram (my $\mathrm{PhD}$ mentor) and I worked with the hypothesis that the virus induced autoimmune reactivity to the myelin surrounding neurons, which they require for insulation and efficient signal transduction. Although there was demyelination occurring, we found no evidence of autoreactive T cells. Instead the paralysis was due to the antiviral $\mathrm{T}$ cell response to infected neurons and oligodendrocytes (16,21). I attended a Gordon Conference in New Hampshire on the topic of neuroimmunology, presenting a poster on my work. Peter Doherty was at the time working on lymphocytic choriomeningitis virus, which also infects the central nervous system, and he was a speaker at the meeting. Peter stopped by my poster to ask me questions. At the end of this conversation, to my surprise, he invited me to visit St. Jude Children's Research Hospital to give a talk. The visit turned into an offer for a postdoctoral position in his laboratory. Thus my introduction to Peter, which was a life and career changing event, was a serendipitous one.

Before I could join his laboratory, I needed to finish my $\mathrm{PhD}$ that was still in early stages of development. I was quite fortunate because the experiments proceeded quickly, though it was still about a year before I defended my dissertation. I joined Peter's laboratory in the summer of 1994.
Peter assigned me to work on a project started by a prior post doc, Christine Ewing. The project involved development of a new, very labor intensive, limiting dilution assay to measure the CD4 $\mathrm{T}$ cell responses to respiratory infection of mice with the parainfluenza Sendai virus (7). Very few laboratories at the time worked on CD4 T cell responses to viruses, and there were few assays. It is worth explaining what a limiting dilution assay involves. The assay begins with infection of mice intranasally with Sendai virus. Lymphocytes are then collected from the lymph nodes and spleens of infected mice at different days and pooled by organ. We then enriched the $\mathrm{CD} 4^{+} \mathrm{T}$ cells by negative selection using magnetic beads, or by flow cytometric sorting. Separately, spleen cells pooled from many mice were depleted of T cells using a Thy 1.2 IgM antibody followed by complement-mediated lysis of cells bearing the antibody. The T-depleted cells are then infected with Sendai virus and incubated overnight, meaning you prepare the antigen presenting cells (APCs) 1 day before the assay. The APCs are plated in 96-well plates in excess numbers relative to the $\mathrm{T}$ cells before addition of the $\mathrm{CD} 4^{+} \mathrm{T}$ cells at different concentrations (also known as dilutions) in 16-24 replicates. After an 18-h incubation, the plates were centrifuged and the supernatants were manually transferred to separate 96well plates. To these plates, we added interleukin-2 (IL-2)dependent Cytotoxic T-Lymphocyte Lymphocyte (CTLL) tumor cells. The CTLL cells proliferate in response to the IL-2 secreted by the virus-specific T cells and this proliferation can be measured by adding radioactive tritiated thymidine to the medium. After another incubation period,

Department of Microbiology and Immunology, David H. Smith Center for Vaccine Biology and Immunology, University of Rochester Medical Center, Rochester, New York.

(C) David J. Topham, 2020; Published by Mary Ann Liebert, Inc. This Open Access article is distributed under the terms of the Creative Commons Attribution Noncommercial License (http://creativecommons.org/licenses/by-nc/4.0/) which permits any noncommercial use, distribution, and reproduction in any medium, provided the original author(s) and the source are cited. 


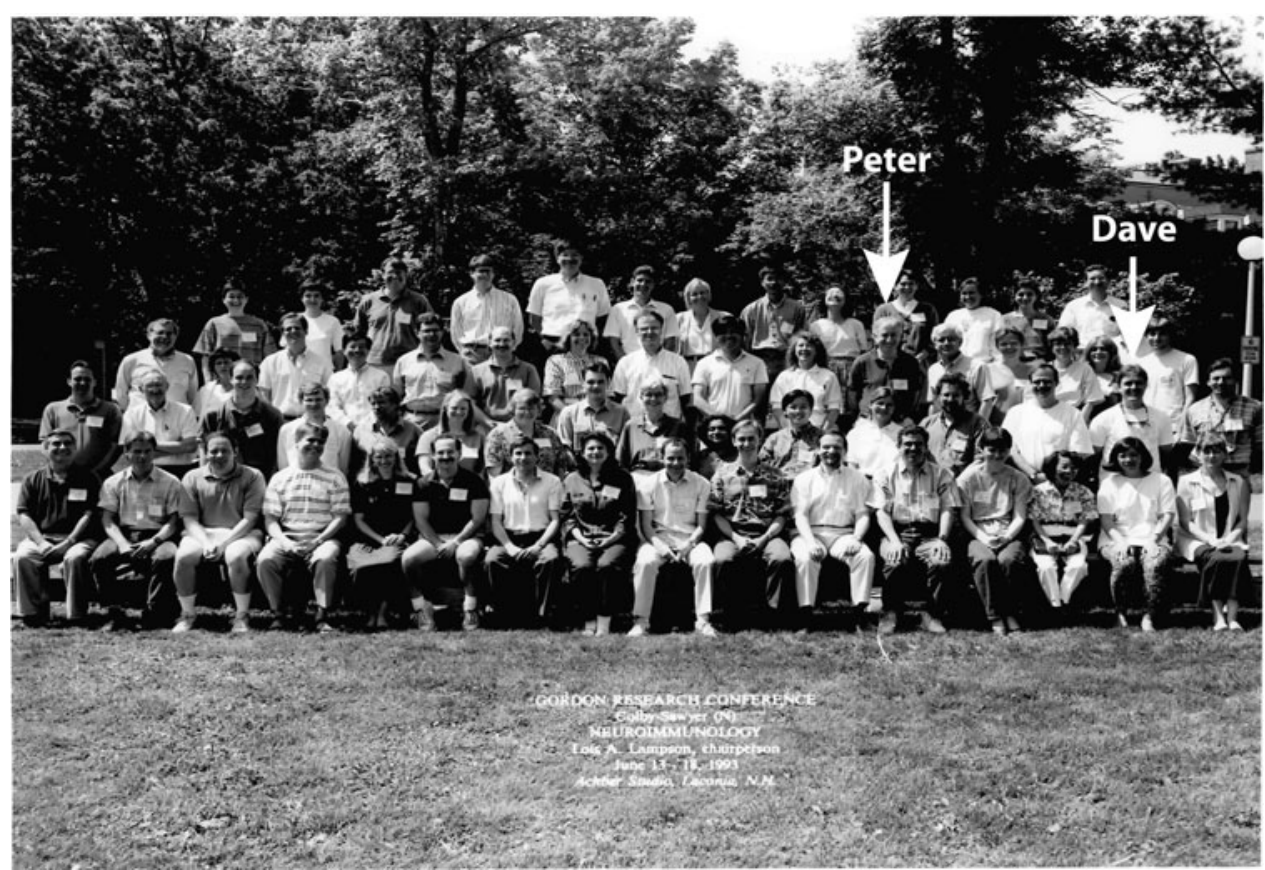

FIG. 1. The 1993 Gordon Conference on neuroimmunology held at Colby-Sawyer College in New London, NH. The arrows point to Peter Doherty and David Topham.

the cells were collected by vacuum filtration onto special 96-well filters and the radioactivity in the cell's residual DNA deposited on the filter was measured. A formula was applied and the frequency of virus-specific cells was calculated. Needless to say, we used thousands of 96-well plates and many pipette tips! Another postdoctoral fellow in the laboratory, Ralph Tripp, performed a similar type of assay to measure cytotoxic $\mathrm{CD}^{+} \mathrm{T}$ cells with radioactive chromium-labeled target cells. Peter once said that together, Ralph and I probably hold the world record for number of LDA assays ever performed, and I think he is right! In a 5-year period, we published a remarkable 15 articles and review articles. Today, we have far less labor, mouse, and tissue culture supply intensive assays.

Shortly after joining Peter's laboratory, Ralph who had been in the laboratory a year or so before me pulled me aside and gave me some very profound advice. He said you are in the Doherty Laboratory and have access to virtually unlimited research resources and current technologies. That in fact is what makes St. Jude such a great place to work. He went on to say that it was entirely up to me as to how productive and successful I would be during my tenure in the laboratory. I could not blame Peter or anyone else if I did not take full advantage of the opportunities that lay before me. This transformed my attitude toward research and drove me to make the best of a very fortunate situation and research environment. I follow this philosophy to this day, and I have been fortunate and successful enough on my own that I can offer the same type of environment to the people in my laboratory today, giving them the same advice Ralph gave to me.

In my time in the Doherty laboratory, we published several seminal articles defining the immune cells and effector functions that clear primary influenza and Sendai virus infections. These were the early days of the genetically engineered knockout mice, and given his position, we had first access to many of the key immune gene knockouts including Class I and II Major Histocompatibility Complex (MHC), B cell and immunoglobulin, Fas, Fas Ligand (FasL), interferon gamma, and perforin. Using these mice along with adoptive cell transfer and bone marrow chimera technologies, we dissected many of the basic and fundamental functions of the immune system during virus infections. I did not recognize the significance of what we were doing at the time, but in retrospect it was phenomenal $(7,24-30)$.

We were the first to quantify the $\mathrm{CD}^{+} \mathrm{T}$ cell kinetics and activation phenotypes during a respiratory virus infection in mice (3). We were able to show that B cell (and immunoglobulin, Ig)-deficient mice could generate a virus-specific $\mathrm{CD}^{+} \mathrm{T}$ cell response that was no different in kinetics or magnitude than their B cell sufficient counterparts (28), although these mice probably have other defects not detected with our techniques. Using mice deficient in MHC Class II with transplanted Class II positive bone marrow, we showed that expression of Class II on the respiratory epithelium was not required to clear virus (29). $\mathrm{CD}^{+} \mathrm{T}$ cells and antibodies were sufficient. The opposite was true for MHC Class I expression in the epithelium, as mice reconstituted with wild-type bone marrow showed delayed virus clearance despite eventually mounting an antiviral antibody response (11). In what has become another seminal work, we showed that $\mathrm{CD}^{+} \mathrm{T}$ cells used both perforin/granzyme and Fas/FasL cooperatively to kill virus-infected cells (27). This was controversial at the time, given that the Fas/FasL pathway is associated with lymphocyte homeostasis $(14,16)$, but has since been corroborated in several other virus infections, including one more of our articles (23). Many of these articles pointed to the fact that in a primary respiratory virus infection, cytotoxic $\mathrm{CD}^{+} \mathrm{T}$ cells are the primary means of controlling the infection until a neutralizing antibody response can develop, which takes 7-10 days. In support of 
this hypothesis, we used $\mathrm{CD}^{+} \mathrm{T}$ cell-depleted mice that were also B cell and Ig deficient to show that $\mathrm{CD}^{+}{ }^{+} \mathrm{T}$ cells, in the absence of $\mathrm{CD}^{+} \mathrm{T}$ cells and $\mathrm{Ig}$, could not control virus infection (25). We also showed that the bone marrow could serve as a site of primary $\mathrm{T}$ cell responses in a situation wherein $\mathrm{T}$ cell trafficking to lymph nodes was disrupted and the spleen was absent (30). Many of these findings are summarized in highly cited review articles written by Peter (2-4).

\section{The Doherty Laboratory}

The laboratory was a great place to work. Although my memories of the comings and goings of the various laboratory members over the years are a little fuzzy, I think we initially had $\sim 8-10$ people, mostly postdoctorals, a few technicians, and a graduate student. We all got along rather well, working and playing hard, often walking up to the "Pinch" neighborhood where there were a couple of bars that we spent many evenings at after work. The beer was cold, and the food was terrible. The places were real dumps, and we loved it. There were also some epic Keystone meetings that many in the laboratory attended, sharing a ski chalet for the duration of the meeting. The laboratory had a reputation of being one of the best laboratories to work in at the institution. This was due to the comradery, the productivity, and the mentoring Peter provided. It stands as one of the best periods of my career. Peter has said to me that the years when Ralph and I were both in the laboratory were the most productive of his career.

\section{The Doherty Laboratory Post-Nobel}

My tenure in the laboratory spanned from 1994 to 1999 , so I was there when Peter and Rolf Zinkernagel were awarded the Nobel prize in Medicine in 1996. I recall getting a phone call $\sim 5$ AM from my father-in-law of all people, who had a habit of listening to news on a short-wave radio. Apparently he was listening when the Nobel prize was announced, and he immediately called us with the news. Peter obviously had gotten a phone call from the Nobel committee some time before that of course. We immediately got up and went in to work (Fig. 2). The first few days were chaotic, mostly for Peter and St. Jude. There was a lot of press, expectedly. That year, my wife Sarah and I decided to stay in town for Thanksgiving, and my parents decided to fly down to Memphis from Boston to join us. On a lark, I invited Peter and his wife Penny to join us for the holiday in our tiny rented townhouse, thinking that of course they would have other plans since becoming famous. I was wrong, Peter enthusiastically accepted my invitation. Dinner went smoothly, and Peter brought several really nice bottles of champagne that were given to him in the dozens by various well-wishers. My parents were a little star struck having Thanksgiving dinner with this year's Nobel laureate in medicine. But in the end we are all just people regardless of the accolades we garner, and both Peter and Penny are delightful guests. They are also gracious hosts. They invited us, including my parents and a few other laboratory folks who stayed in town for the holiday to their house the next day to continue the celebration, and maybe kill off some more

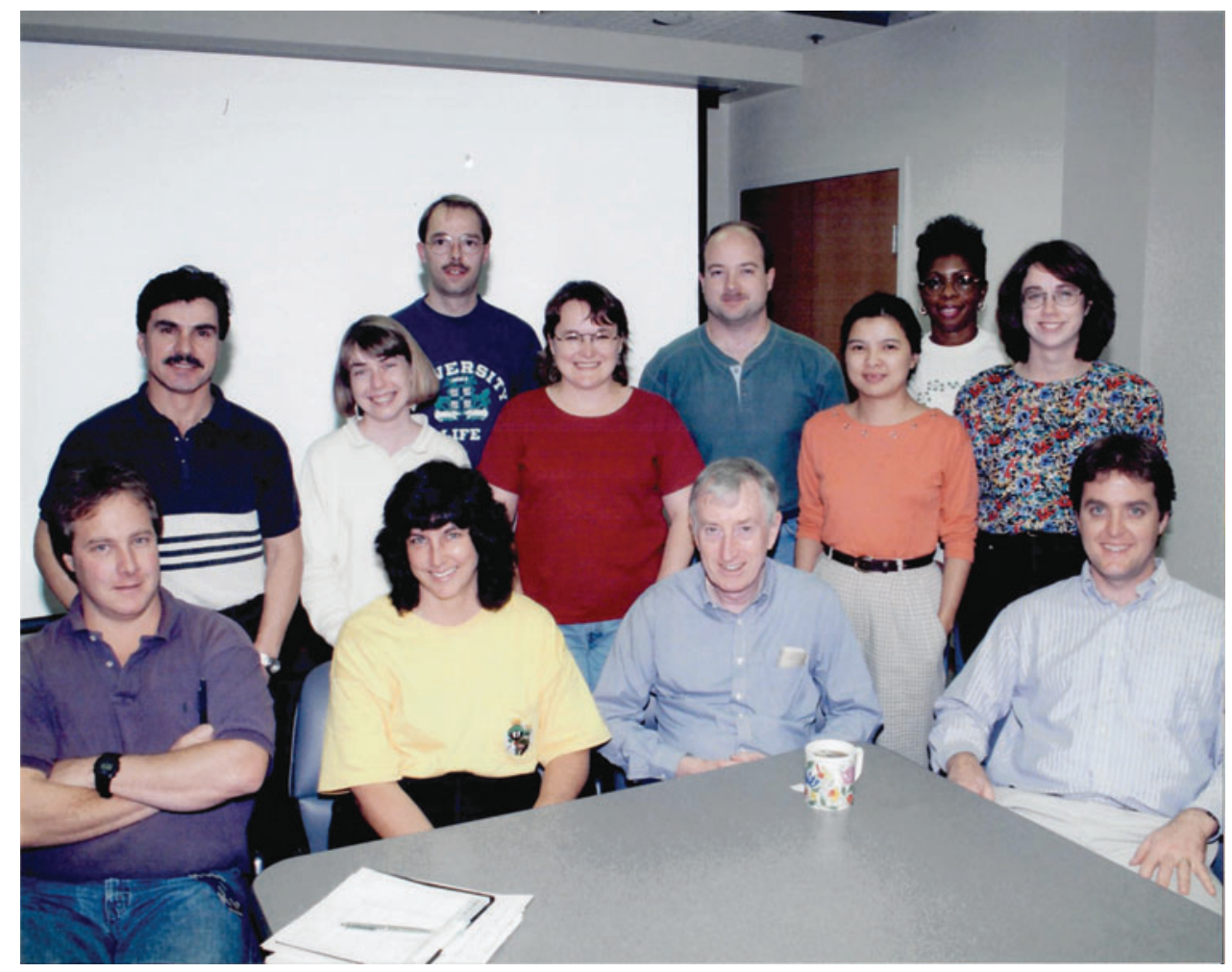

FIG. 2. The Doherty Laboratory 1996 post-Nobel. Front Row (L-R): Ralph Tripp, Ann Marie Hamilton Easton, Peter Doherty, and David Topham. Middle Row (L-R): Mehdi Mehrpooya, Janice Riberdy, Rhonda Cardin, Xiao-yan Mo, and Kristin Branum. Back Row (L-R): Jan Christensen, James Brooks, and Suzette Wingo. 
champagne. My mother asked for a tour of the house, a restored Craftsmen design with beautiful wood throughout. Peter had a gas fireplace in the living room and my mother asked him how it worked. He offered to demonstrate. He turned on the gas and then fumbled to get a match lit. By the time he did, a giant fireball erupted from the fireplace as the gas had built up. Everyone was OK, but the next thing we smelled was burning hair. The fireball had singed the eyebrows off Peter's face! I was of course mortified, but next you know, Ralph Tripp bursts out laughing that made everyone else crack up at Peter's expense. Peter of course took it all in stride and laughed along with the rest of us. Not many know this, but he had to go accept the Nobel prize with no eyebrows!

In the last months of my time in Peter's laboratory, we were approached by a group of scientists from Biogen, a biotech company in Cambridge, MA. They were part of the company's integrin division and sought partners to collaborate with to determine the functions of certain integrins in the immune system. Peter was not very interested in the work at the time and left it to me and Jan Christensen, another postdoctoral in the laboratory, to do the work. Two of the integrins they were interested in were very late antigen (VLA)-1 and VLA-2. These are alpha/beta heterodimers and are distinguished by the alpha chain expressed $(1,5,8,9)$. VLA-1 is alpha-1/beta-1 and VLA-2 is alpha-2/ beta-1. They also go by the cluster differentiation nomenclature as CD49a/CD29 and CD49b/CD29, respectively. These integrins bind collagens I and IV in the extracellular matrix $(1,5,8,9)$. Biogen supplied us with copious amounts of antibodies to the two alpha chains and Jan and I began experiments with influenza-infected mice performing flow cytometry to determine expression kinetics, followed by administering these blocking antibodies to mice to see whether this altered the acute CD4 and CD8 T cell responses to the infection. We tried every possible combination and dosing schedule, but to no avail. We could not see any effects on the acute immune response. Perhaps this was also why Peter had little interest in the project. I took the project and the collaboration with me when I left the laboratory in 1999 to start my own laboratory at the University of Rochester in Rochester, NY. I continued with similar experimental approaches but did not get any further than I did in the Doherty laboratory. I should note that it was Peter's suggestion to look at Rochester since he knew that Dr. Tim Mosmann was starting a new vaccine biology and immunology center there. I did not know Tim or Rochester very well, but in another serendipitous encounter, I met Tim at an invitation only symposium on immune memory being hosted by the Trudeau Institute in Saranac Lake, NY. It was at that chance meeting that Tim and I were introduced, which led to the interview and faculty position in Rochester.

In around 2001 or 2002, I attended a regional immunology symposium hosted by my alma mater the University of Vermont held in the Fall at the Bolton Valley Ski "resort." The meeting attracted investigators and students from surrounding schools such as the University of Connecticut, UVM, Dartmouth, the Trudeau Institute, and McGill University. I believe David Masopust was a $\mathrm{PhD}$ student at the time in the laboratory of Dr. Leo LeFrancois at UConn. David presented the results of experiments he performed infecting mice systemically with Listeria monocytogenes and vesicular stomatitis virus, discovering that effector memory CD8 T cells distributed to all nonlymphoid organs upon recovery from infection (15). THE LIGHTBULB WENT OFF IN MY HEAD! I instantly knew what the collagen binding integrins might be doing. I returned to my laboratory in Rochester and instructed my graduate student Steven Ray to treat "memory" mice (mice recovered from influenza infection 2-3 months prior) with the CD49a and CD 49b blocking antibodies. I then asked him to sample the lungs and lymphoid organs for the presence of virus-specific CD8 T cells using MHC class I tetramers to the immunodominant nucleoprotein and acid polymerase peptide antigens from the virus. Lo and, behold, the virus-specific memory CD8 $\mathrm{T}$ cells, had left all the peripheral nonlymphoid tissues and had drained into the lymphoid organs in the anti-CD49a-treated mice (18). The next experiment was to challenge these mice with a secondary lethal dose of a heterologous influenza virus (H1N1 PR8). All the mice in the anti-CD49a-treated mice succumbed to infection, whereas all the mice in the isotype control group survived (18). We wrote up the work and sent it to Immunity where it was reviewed and initially rejected. The reviewers wanted CD49a-deficient mice and T cells to be used in conjunction with our antibody blocking. It took over a year to acquire the mice, breed them, cross them to $\mathrm{T}$ cell Receptor (TCR) transgenic mice, set up memory mice, and perform the secondary challenge studies. The results were the same, and the article went back off to Immunity. The article was accepted and a few months later, I received my first R01 on the topic.

I tell this story because in the course of writing up that article, we coined the term "Tissue Resident Memory" in one of the section headings. In the discussion, we interpreted the overall results to indicate these $\mathrm{CD} 49 \mathrm{a}^{+}$cells to be memory cells "resident in the peripheral nonlymphoid tissues" (18). This launched what has now become a major arm of the immunology field. I do not know when the term Tissue Resident Memory $\left(\mathrm{T}_{\mathrm{RM}}\right)$ fell into wide use. Klonowski and Lefrancois continued their work on the topic, performing seminal parabiosis experiments to demonstrate that the $\mathrm{T}_{\mathrm{RM}}$ was nonrecirculating cells (12). Unfortunately, the CD49a fluorescently labeled antibodies were not commercially available until very recently. We were obtaining our labeled antibodies from Biogen and later had them custom conjugated (at great expense) by the vendor. Biogen closed their integrin division after the Tysabri (anti-CD49d) clinical studies in multiple sclerosis wherein several treated subjects developed lethal progressive multifocal leukoencephalopathy or PML, a rare brain disease caused by a virus (10). The drug was too good at immunosuppression. As a consequence of the limited availability of the labeled anti-CD49a antibodies, CD49a did not initially take off in the field as a marker of $\mathrm{T}_{\mathrm{RM}}$. Instead two other proteins expressed by some $\mathrm{T}_{\mathrm{RM}}$, CD69 and CD103, took hold in the field. Recently more articles are using CD49a as the labeled antibodies are available commercially now. I can tell you that CD49a is the more relevant "marker" for $\mathrm{T}_{\mathrm{RM}}$ as we will show in a series of articles currently under review or in stages of submission.

I tell this story for another reason. It is an example of the lingering and permanent impact Peter Doherty had on my career as well as on the immunology field. There are many of 
these examples. Peter cannot take credit for discovering the role of CD49a, but he mentored me to become a wellestablished influenza immunologist and inspired me to make the discoveries we made both while in his laboratory and thereafter. My laboratory continues to work on CD49a and $\mathrm{T}_{\mathrm{RM}}$ to this day, as they are important in the quest for universal influenza vaccines deemed a priority in the National Institute of Allergy and Infectious Disease's strategic plan (6). Our current work on the topic utilizes a novel influenza tracheitis mouse model of infection for studying CD8 T cell motility in the infected and recovered trachea $(13,20)$. We have found that CD49a and CD103 are not just "markers" of the $\mathrm{T}_{\mathrm{RM}}$ phenotype, they also regulate their motility in the tissue and interactions with epithelial cells (19). Interestingly, CD49a is required for $\mathrm{T}$ cell locomotion in the tissue, presumably by binding extracellular matrix (ECM) collagens (unpublished observation). We have a project that is part of a larger program project (Dr. Deb Fowell, PI) on immune imaging that was just refunded for another 5 years. This work stemming from Peter's laboratory has become a major component of my professional career and identity as a scientist.

Peter's trainees, along with those of his colleague Dr. Rob Webster, not to mention Rob and Peter themselves, have had a major influence over the entire influenza research field. In the days when we were at St. Jude, influenza research was not the most popular topic in the virology or immunology fields and funding was limited. Many scientists did not believe in Rob's hypothesis that pandemic viruses emerge from animal reservoirs (17), which we now know is true. With the advent of the lethal avian H5N1 outbreak of 1997, priorities within National Institute of Allergy and Infectious Disease (NIAID) began to shift toward influenza. A Center of Excellence in Influenza Research and Surveillance (CEIRS) was established at St. Jude shortly after the 1997 outbreak. In 2007, the CEIRS was turned into a network of five large centers. Rochester was fortunate enough to successfully compete for one of them initially led by Dr. John Treanor as Principal Investigator (PI) and director, and me as co-PI and codirector. The CEIRS network was recompeted in 2013-2014, and we retained our center for another round. I became director and PI of the Rochester center (the New York Influenza Center of Excellence or NYICE) in 2018 upon Dr. Treanor's retirement. Many of the CEIRS network investigators originated from a small group of laboratories that included the Doherty and Webster laboratories. Their trainees were now the leaders in the field. The CEIRS network has been very successful as a network and is considered among NIAID's crown jewels. I think some of this is because so many of us trained together and have a level of trust among one another. I would like to say that we are successful because we are good but have to give the nod to serendipity once again. Many of us trained in the study of influenza viruses and immune responses at a time before the field exploded. Being in the right place at the right time to take advantage of the new funding opportunities coming from NIAID and others is a big part of our success. No one, with the possible exception of Dr. Webster, saw the flu threat coming. We are now much better prepared to deal with emerging viruses and much work is being done to improve influenza vaccines as well as better understand human immune responses to influenza so that vaccines may be more rationally designed.

\section{Closing Remarks}

It has been enjoyable to reflect back on such a remarkable time of my life and consider Peter's influence on it. Too often we take full credit for our own success when in reality individual success involves many people and the ability to recognize and make good of the opportunities that we find before us. I could not have charted in advance the path my career has taken. And that path was determined by several key forks in the road. I feel fortunate to have had the privilege of working with Peter and the people in his laboratory, even if it was but for a fleeting moment in a lifetime.

\section{Author Disclosure Statement}

No competing financial interests exist.

\section{Funding Information}

The author is currently funded by National Institute of Allergy and Infectious Disease grant and contract numbers: HHSN272201400005C, AI102851, AI12998, and AI131348.

\section{References}

1. Bank I, Book M, and Ware R. Functional role of VLA-1 (CD49A) in adhesion, cation-dependent spreading, and activation of cultured human T lymphocytes. Cell Immunol 1994;156:424-437.

2. Doherty PC, Hamilton-Easton AM, Topham DJ, et al. Consequences of viral infections for lymphocyte compartmentalization and homeostasis. Semin Immunol 1997;9: 365-373.

3. Doherty PC, Topham DJ, and Tripp RA. Establishment and persistence of virus-specific CD4+ and CD8+ $\mathrm{T}$ cell memory. Immunol Rev 1996;150:23-44.

4. Doherty PC, Topham DJ, Tripp RA, et al. Effector CD4+ and CD8+ T-cell mechanisms in the control of respiratory virus infections. Immunol Rev 1997;159:105-117.

5. Elices MJ, and Hemler ME. The human integrin VLA-2 is a collagen receptor on some cells and a collagen/laminin receptor on others. Proc Natl Acad Sci U S A 1989;86: 9906-9910.

6. Erbelding EJ, Post D, Stemmy E, et al. A universal influenza vaccine: the strategic plan for the National Institute of Allergy and Infectious Diseases. J Infect Dis 2018;218: 347-354.

7. Ewing C, Topham DJ, and Doherty PC. Prevalence and activation phenotype of Sendai virus-specific CD4+ T cells. Virology 1995;210:179-185.

8. Hemler ME, and Jacobson JG. Cell matrix adhesion-related proteins VLA-1 and VLA-2: regulation of expression on T cells. J Immunol 1987;138:2941-2948.

9. Hemler ME, Jacobson JG, and Strominger JL. Biochemical characterization of VLA-1 and VLA-2. Cell surface heterodimers on activated T cells. J Biol Chem 1985;260: $15246-15252$.

10. Ho P-R, Koendgen $\mathrm{H}$, Campbell $\mathrm{N}$, et al. Risk of natalizumab-associated progressive multifocal leukoencephalopathy in patients with multiple sclerosis: a retrospective analysis of data from four clinical studies. Lancet Neurol 2017;16:925-933.

11. Hou S, and Doherty PC. Clearance of Sendai virus by $\mathrm{CD} 8+\mathrm{T}$ cells requires direct targeting to virus-infected epithelium. Eur J Immunol 1995;25:111-116. 
12. Klonowski KD, Williams KJ, Marzo AL, et al. Dynamics of blood-borne CD8 memory $\mathrm{T}$ cell migration in vivo. Immunity 2004;20:551-562.

13. Lambert Emo K, Hyun YM, Reilly E, et al. Live imaging of influenza infection of the trachea reveals dynamic regulation of CD8+ T cell motility by antigen. PLoS Pathog 2016; 12:e1005881.

14. Lynch DH, Ramsdell F, and Alderson MR. Fas and FasL in the homeostatic regulation of immune responses. Immunol Today 1995; 16:569-574.

15. Masopust D, Vezys V, Marzo AL, and Lefrancois L. Preferential localization of effector memory cells in nonlymphoid tissue. Science 2001;291:2413-2417.

16. Nagata $S$. Apoptosis regulated by a death factor and its receptor: fas ligand and Fas. Philos Trans R Soc Lond B Biol Sci 1994;345:281-287.

17. Pereira HG, Tumova B, and Webster RG. Antigenic relationship between influenza A viruses of human and avian origins. Nature 1967;215:982-983.

18. Ray SJ, Franki SN, Pierce RH, et al. The collagen binding alphalbeta1 integrin VLA-1 regulates CD8 T cell-mediated immune protection against heterologous influenza infection. Immunity 2004;20:167-179.

19. Reilly EC, Lambert-Emo K, Reilly N, et al. TRM Integrins CD103 and CD49a Differentially Support Adherence and Motility After Resolution of Influenza Virus Infection. bioRxiv 2020.02.14.947986; doi: https://doi.org/10.1101/ 2020.02.14.947986.

20. Reilly EC, Lambert-Emo K, and Topham DJ. The effects of acute neutrophil depletion on resolution of acute influenza infection, establishment of tissue resident memory (TRM), and heterosubtypic immunity. PLoS One 2016;11:e0164247.

21. Sriram S, Topham DJ, Huang SK, and Rodriguez M. Treatment of encephalomyocarditis virus-induced central nervous system demyelination with monoclonal anti-T-cell antibodies. J Virol 1989;63:4242-4248.

22. Topham DJ, Adesina A, Shenoy M, Craighead JE, and Sriram S. Indirect role of $\mathrm{T}$ cells in development of polioencephalitis and encephalomyelitis induced by encephalomyocarditis virus. J Virol 1991;65:3238-3245.
23. Topham DJ, Cardin RC, Christensen JP, et al. Perforin and Fas in murine gammaherpesvirus-specific CD8(+) T cell control and morbidity. J Gen Virol 2001;82:1971-1981.

24. Topham DJ, Castrucci MR, Wingo FS, Belz GT, and Doherty PC. The role of antigen in the localization of naive, acutely activated, and memory CD8(+) T cells to the lung during influenza pneumonia. J Immunol 2001;167:69836990.

25. Topham DJ, and Doherty PC. Clearance of an influenza A virus by $\mathrm{CD} 4+\mathrm{T}$ cells is inefficient in the absence of $\mathrm{B}$ cells. J Virol 1998;72:882-885.

26. Topham DJ, and Doherty PC. Longitudinal analysis of the acute Sendai virus-specific CD4+ $\mathrm{T}$ cell response and memory. J Immunol 1998;161:4530-4535.

27. Topham DJ, Tripp RA, and Doherty PC. CD8+ T cells clear influenza virus by perforin or Fas-dependent processes. J Immunol 1997;159:5197-5200.

28. Topham DJ, Tripp RA, Hamilton-Easton AM, Sarawar SR, and Doherty PC. Quantitative analysis of the influenza virus-specific CD4+ $\mathrm{T}$ cell memory in the absence of $\mathrm{B}$ cells and Ig. J Immunol 1996;157:2947-2952.

29. Topham DJ, Tripp RA, Sarawar SR, Sangster MY, and Doherty PC. Immune CD4+ T cells promote the clearance of influenza virus from major histocompatibility complex class II -/- respiratory epithelium. J Virol 1996;70:12881291.

30. Tripp RA, Topham DJ, Watson SR, and Doherty PC. Bone marrow can function as a lymphoid organ during a primary immune response under conditions of disrupted lymphocyte trafficking. J Immunol 1997;158:3716-3720.

Address correspondence to:

Dr. David J. Topham

Department of Microbiology and Immunology David H. Smith Center for Vaccine Biology and Immunology

University of Rochester Medical Center Rochester, NY 14642

E-mail: david_topham@urmc.rochester.edu 